\title{
ANTIMUTAGENIC EFFECT OF PHENETHYL ISOTHIOCYANATE
}

\author{
Petr Šmerák ${ }^{1}$, Zdeňka Polívková ${ }^{1}$, Rudolf Štětina ${ }^{2}$, Jiřina Bártováa , Ivo Bárta† \\ ${ }^{1}$ Charles University in Prague, 3rd Faculty of Medicine, Department of General Biology and Genetics, Prague, Czech Republic \\ ${ }^{2}$ Faculty of Military Medical Health Sciences, Department of Toxicology, Hradec Králové, Czech Republic \\ ${ }^{3}$ Charles University in Prague, 3rd Faculty of Medicine, Department of General Hygiene, Prague, Czech Republic
}

\section{SUMMARY}

Using the Ames bacterial mutagenicity test, the comet assay, and an in vivo micronucleus test, we investigated the effect of the chemoprotective substance phenethyl isothiocyanate (PEITC) on the mutagenic activity of indirect-acting mutagens and carcinogens aflatoxin B1 (AFB1) and 2-amino-3-methylimidazo[4,5-f]quinoline (IQ), and direct-acting mutagen and carcinogen N-nitroso-N-methylurea (MNU).

In the Ames test, the antimutagenic activity of PEITC was studied in the concentration range $0.3-300 \mu \mathrm{g} / \mathrm{plate}$. PEITC at concentrations of 0.3, 3 and $30 \mu \mathrm{g} /$ plate reduced dose-dependently mutagenicity of AFB1 and IQ in both S.typhimurium TA98 and TA100 strains. In the case of the direct mutagen MNU, the antimutagenic effect of PEITC was detected only at concentration of $30 \mu \mathrm{g} / \mathrm{plate}$ in the strain TA100. The PEITC concentration $300 \mu \mathrm{g} /$ plate was toxic in the Ames test. The $24 \mathrm{~h}$ pre-treatment of HepG2 cells with PEITC at concentration $0.15 \mu \mathrm{g} / \mathrm{ml}$ resulted in a significant decrease of DNA breaks induced by MNU at concentrations 0.25 and $0.5 \mathrm{mM}$. Although a trend towards reduced strand break level were determined also at PEITC concentrations 0.035 and $0.07 \mu \mathrm{g} / \mathrm{ml}$ it did not reach the statistical significance. No effect, however, of PEITC on IQ-induced DNA breaks was observed. Chemopreventive effect of PEITC was revealed also in vivo. Pretreatment of mice with PEITC concentrations of 25 and $12.5 \mathrm{mg} / \mathrm{kg} \mathrm{b.w}$. administered to mice in three daily doses resulted in reduction of micronucleus formation in mice exposed to all three mutagens under study, with statistically significant effect at concentration of $25 \mathrm{mg} / \mathrm{kg}$.

Results of this study indicate that the strong PEITC antimutagenic properties may have an important role in the prevention of carcinogenesis and other chronic degenerative diseases that share some common pathogenetic mechanisms.

Key words: phenethyl isothiocyanate, aflatoxin B1, 2-amino-3-methylimidazo [4,5-]quinoline, N-nitroso-N-methylurea, Ames test, micronucleus test, comet assay

Address for correspondence: P. Šmerák, 3rd Faculty of Medicine, Dept. of General Biology and Genetics, Ruská 87, 10000 Prague 10, Czech Republic. E-mail: smerak@gmail.com

\section{INTRODUCTION}

The development of tumours is a very complex process in which internal (genetic) factors as well as factors from the external environment participate, the latter being predominant.

The interindividual variability in cancer expression is due to differences in the amount of DNA damage and capacity to repair that damage. Both the amount of DNA damage and the individual repair capacity are influenced by the genetic predisposition (gene polymorphism) and by dietary factors. Dietary factors play also important role in biotransformation and detoxification of genotoxic chemicals.

The tumourigenesis is a multistep process that can be activated by environmental carcinogens, inflamatory agens and tumour promotors. These factors are known to modulate transcription factors, antiapoptotic or proapoptotic proteins, protein kinases, cell cycle proteins, cell adhesion molecules and growth factor signalling pathways. All these molecular targets can be influenced by some plant components that display biochemical and biological activities capable of preventing carcinogensis $(1,2)$.

One of the rational and effective strategies for chemoprevention is the blockade of DNA damage caused by carcinogenic insult.
Complementary strategy is to render organism more resistant to mutagens/carcinogenes and/or to inhibit the progression of the disease (3). The experimental in vitro and in vivo studies have demonstrated that some dietary components - phytochemicals or compounds that come from edible plants - have inhibitory effects on human cancers suggesting that they may serve as chemopreventive agents $(4,5)$.

We have also demonstrated the antimutagenic and immunomodulatory effect of substances found in raw vegetables against mutagenicity or immunosuppression caused by $\mathrm{AFB}_{1}$, and pyrolysates of aminoacids (6-10).

Numerous epidemiological studies indicate that Brassica vegetables protect humans against cancer (11). Anti-carcinogenic effect of cruciferous vegetables is attributed to organic isothiocyanates (ITCs) that occur naturally as thioglucoside conjugates (glucosinolates) in a variety of edible cruciferous vegetables. The glucosinolates are hydrolyzed upon chewing or maceration by the enzyme myrosinase to release the isothiocyanate as well as other products. The isothiocyanates are among the most potent anticarcinogenic agents known to reduce occurrence of cancer in different organs including oesophagus, lung and stomach in animal models (reviewed in 12). 
One of the most important mechanisms of cancer-chemopreventive activities of isothiocyanates is a modulation of Phase I and Phase II enzymes resulting in reduced activation and/or increased detoxification of carcinogens. Together with modulation of xenobiotic metabolism, modulation of antioxidant defense system may decrease cellular damage by reactive compounds (13-16).

Natural and synthetic isothiocyanates (ITC) have demonstrated cancer-preventive properties in animals treated with chemical carcinogens, including polycyclic aromatic hydrocarbons and nitrosamines (17-19). Phenethyl isothiocyanate (PEITC) reduced the occurrence of experimentally induced tumours in mice, it seems to be very active during tumour initiation $(12,20)$. Certain ITCs inhibit the proliferation of cultured cancer cell lines by causing cell cycle arrest and/or induction of apoptosis. PEITC inhibits proliferation and induces apoptosis of PC-3 human prostate cancer cells (21), rapidly induces growth inhibition of human promyelocytic leukemia HL60/S cells (22), it is cytotoxic for human breast cancer MCF-7 and mammary epithelial MCF-12A cell lines (23), enhances apoptosis of pulmonary alveolar macrophages and bronchial epithelial cells (24). It inhibits angiogenesis in vitro and ex vivo even at concentrations achievable by dietary intervention or pharmacologic administration (25). PEITC was proved to be active in the inhibition of the aberrant promotor methylation of GSTP1 gene which is critically inactivated in prostate cancer cells (26). Some molecular targets involved in antiproliferative and proapoptotic activity of PEITC was described by Pullar et al. (27).

Antimutagenic properties of PEITC were detected in several studies. The inhibition of genotoxic effect of dimethylnitroso-amine (DMN) and 2-amino-1methyl-6-phenylimidazo[4,5-b]pyridine (PhIP) by PEITC was detected in the Ames and the micronucleus tests (28), the effect of PEITC on mutagenicity of IQ and other heterocyclic amines in the Ames test (29). Modulation of the clastogenic effect of mitomycine $\mathrm{C}$ and cyclophosphamide by PEITC was detected in bone marrow cells of mice (30). The protective effect of isothiocyanates towards $\mathrm{N}$-nitrosamine induced DNA damage was proved in HepG2 cells by the single-cell gel electrophoresis assay (31).

In the present study, we investigated the effect of PEITC on the mutagenicity of three known mutagens/carcinogens: aflatoxin $\mathrm{B}_{1}\left(\mathrm{AFB}_{1}\right)$, 2-amino-3-methylimidazo[4,5-f]quinoline (IQ) and N-nitroso-N-methylurea (MNU). Antimutagenic effect of PEITC was detected using the Ames bacterial mutagenicity test, the comet assay on human cell cultures and the micronucleus in vivo test.

Table 1. Effect of PEITC on the mutagenicity of AFB1 in the Ames test (S. typhimurium TA98, TA100)

\begin{tabular}{|c|c|c|c|c|c|c|}
\hline \multirow{2}{*}{$\begin{array}{l}\text { AFB1+PEITC dose } \\
\text { (mg/plate) }\end{array}$} & \multicolumn{3}{|c|}{ S. typhimurium TA98+S9 } & \multicolumn{3}{|c|}{ S. typhimurium TA100+S9 } \\
\hline & No. of revertants & $\pm \mathrm{SD}$ & $\%$ of inhibition & No. of revertants & $\pm \mathrm{SD}$ & $\%$ of inhibition \\
\hline $10+0$ & 908 & 109 & & 1,377 & 63 & \\
\hline $10+0.3$ & 941 & 138 & +4 & 1,353 & 57 & -2 \\
\hline $10+3$ & $624^{*}$ & 50 & -31 & $965^{* *}$ & 64 & -30 \\
\hline $10+30$ & $52^{* *}$ & 34 & -94 & $161^{\star *}$ & 82 & -88 \\
\hline $10+300$ & 0 & & - & 0 & & - \\
\hline $1+0$ & 440 & 106 & & 852 & 80 & \\
\hline $1+0.3$ & $309 *$ & 52 & -30 & $536^{* *}$ & 93 & -37 \\
\hline $1+3$ & $154^{* *}$ & 48 & -65 & $372^{\star *}$ & 34 & -56 \\
\hline $1+30$ & $39 * *$ & 23 & -91 & $94^{* *}$ & 29 & -89 \\
\hline $1+300$ & 0 & & - & 0 & & - \\
\hline $0.1+0$ & 120 & 12 & & 391 & 32 & \\
\hline $0.1+0.3$ & 102 & 15 & -15 & $259 * *$ & 57 & -34 \\
\hline $0.1+3$ & $76^{* *}$ & 17 & -37 & $199 * *$ & 25 & -49 \\
\hline $0.1+30$ & $17^{* *}$ & 8 & -86 & $69 * *$ & 21 & -82 \\
\hline $0.1+300$ & 0 & & - & 0 & & - \\
\hline Control (DMSO) & 23 & 3 & & 110 & 14 & \\
\hline $0+0.3$ & 26 & 5 & & 102 & 8 & \\
\hline $0+3$ & 30 & 3 & & 103 & 12 & \\
\hline $0+30$ & 21 & 5 & & 79 & 19 & \\
\hline $0+300$ & 0 & & & 0 & & \\
\hline
\end{tabular}

*Statistically significant difference between the sample with PEITC and mutagen and the sample with mutagen alone: $p<0.05$

${ }^{* *}$ Statistically significant difference between the sample with PEITC and mutagen and the sample with mutagen alone: $p<0.01$

SD: standard deviation 
Table 2. Effect of PEITC on the mutagenicity of IQ in the Ames test (S. typhimurium TA98, TA100)

\begin{tabular}{|c|c|c|c|c|c|c|c|}
\hline \multirow{2}{*}{$\begin{array}{l}\text { IQ+PEITC dose } \\
\text { (mg/plate) }\end{array}$} & \multicolumn{3}{|c|}{ S. typhimurium TA98+S9 } & \multicolumn{4}{|c|}{ S. typhimurium TA100+S9 } \\
\hline & $\begin{array}{l}\text { No. of rever- } \\
\text { tants }\end{array}$ & $\pm S D$ & $\%$ of inhibition & dose (g/plate) & $\begin{array}{l}\text { No. of rever- } \\
\text { tants }\end{array}$ & $\pm \mathrm{SD}$ & $\%$ of inhibition \\
\hline $0.1+0$ & 1,080 & 44 & & $10+0$ & 1,710 & 216 & \\
\hline $0.1+0.3$ & $764^{* *}$ & 85 & -29 & $10+0.3$ & 1,517 & 128 & -11 \\
\hline $0.1+3$ & $238^{* *}$ & 38 & -78 & $10+3$ & $706^{* *}$ & 148 & -59 \\
\hline $0.1+30$ & $13^{* *}$ & 4 & -99 & $10+30$ & $98^{* *}$ & 35 & -94 \\
\hline $0.1+300$ & 0 & & - & $10+300$ & 0 & & - \\
\hline $0.01+0$ & 310 & 35 & & $1+0$ & 648 & 103 & \\
\hline $0.01+0.3$ & $220^{* *}$ & 51 & -29 & $1+0.3$ & $432^{* *}$ & 27 & -33 \\
\hline $0.01+3$ & $75^{* *}$ & 10 & -76 & $1+3$ & $225^{\star *}$ & 77 & -65 \\
\hline $0.01+30$ & $23^{* *}$ & 19 & -93 & $1+30$ & $87^{* *}$ & 27 & -87 \\
\hline $0.01+300$ & 0 & & - & $1+300$ & 0 & & - \\
\hline $0.001+0$ & 97 & 9 & & $0.1+0$ & 206 & 24 & \\
\hline $0.001+0.3$ & $58^{* *}$ & 9 & -40 & $0.1+0.3$ & $154^{* *}$ & 7 & -25 \\
\hline $0.001+3$ & $32^{* *}$ & 5 & -67 & $0.1+3$ & $110^{* *}$ & 25 & -47 \\
\hline $0.001+30$ & $25^{* *}$ & 12 & -74 & $0.1+30$ & $82^{* *}$ & 15 & -60 \\
\hline $0.001+300$ & 0 & & - & $0.1+300$ & 0 & & - \\
\hline Control (DMSO) & 25 & 5 & & Control (DMSO) & 93 & 19 & \\
\hline $0+0.3$ & 28 & 4 & & $0+0.3$ & 91 & 9 & \\
\hline $0+3$ & 29 & 4 & & $0+3$ & 85 & 8 & \\
\hline $0+30$ & 20 & 7 & & $0+30$ & 83 & 3 & \\
\hline $0+300$ & 0 & & & $0+300$ & 0 & & \\
\hline
\end{tabular}

${ }^{*}$ Statistically significant difference between the sample with PEITC and mutagen and the sample with mutagen alone: $p<0.01$

SD: standard deviation

\section{MATERIAL AND METHODS}

\section{The Ames Test}

For the evaluation of antimutagenic effect of PEITC in vitro, the Ames test with Salmonella typhimurium TA98 and TA100 (32, 33, 34) was used. Mutagenic substances were used at the following concentrations: $\mathrm{AFB}_{1}$ at concentrations of $10 \mu \mathrm{g}, 1 \mu \mathrm{g}$ and $0.1 \mu \mathrm{g}$ per plate in both strains, TA98 and TA100, IQ at concentrations of $0.1 \mu \mathrm{g}, 0.01 \mu \mathrm{g}$ and $0.001 \mu \mathrm{g}$ per plate in the strain TA98, at concentrations of $10 \mu \mathrm{g}, 1 \mu \mathrm{g}$ and $0.1 \mu \mathrm{g}$ in the strain TA100, MNU at concentrations of $1000 \mu \mathrm{g}, 100 \mu \mathrm{g}$ and $10 \mu \mathrm{g}$ only in the strain TA100 as these concentrations had no effect in the strain TA98. Each concentration of each mutagen was combined with four different concentrations of PEITC ( $300 \mu \mathrm{g}, 30 \mu \mathrm{g}, 3 \mu \mathrm{g}$, and $0.3 \mu$ g per plate). All chemicals were diluted in DMSO. The S9 fraction of liver homogenate from male Wistar albino rats induced by a mixture of polychlorinated biphenyls Delor 103 was used for metabolic activation of indirect mutagens (33). Each combination of mutagen and antimutagen was tested in two separate experiments with three plates in each experiment.
The percentage of inhibition of the mutagenicity was calculated by the formula:

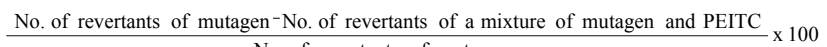
No. of revertants of mutagen

Statistical evaluation was carried out using Student's t-test.

\section{The Micronucleus Test}

In vivo bone marrow micronucleus test was carried out on male Balb C mice, each weighting 20-24 g (BIOTEST, Konárovice). The animals were housed under standard conditions and were fed with a commercial granulated mixture for laboratory rodents. Animals were divided into group of 6 mice each.

PEITC was applied per os at the doses of $25 \mathrm{mg} / \mathrm{kg}$ and $12.5 \mathrm{mg} / \mathrm{kg}$ of the murine body weight for three consecutive days by gavage. The mutagens were administered at one dose on the third day, 1-1.5 $\mathrm{h}$ after the application of PEITC $\left(\mathrm{AFB}_{1}\right.$ at the dose of $1 \mathrm{mg} / \mathrm{kg}$ b.w., IQ at the dose of $20 \mathrm{mg} / \mathrm{kg}$ b.w., MNU at the dose of $50 \mathrm{mg} / \mathrm{kg}$ b.w.). All substances were dissolved in 7\% 
DMSO and applied in volumes of $0.1 \mathrm{ml} / 10 \mathrm{~g}$ b.w. The control group obtained equal amounts of the solvent (7\% DMSO).

The mouse bone marrow micronucleus test was carried out according to Schmid (35). A total of 1,000 polychromatophilic erythrocytes were scored per animal. Each experiment was performed twice. The statistical evaluation was carried out using the Student's t-test.

\section{The Comet Assay}

The amount of single strand DNA breaks (SSB) induced in HepG2 cells pretreated with PEITC and treated subsequently with MNU or IQ was measured by the comet assay. The alkaline version of the comet assay according to Singh et al. (36) modified by Collins et al. (37) was used. Briefly, cells embedded in agarose on a microscope slide were lysed in high-salt buffer containing non-ionic detergent and left to unwind the DNA in alkaline electrophoresis solution. During the following electrophoresis the DNA migrates to the anode. After the staining of cells with fluorescent dye (ethidium bromide, Sigma) cells in fluorescent microscope resembles comets. The amount of DNA in the tail of comets reflects the amount of the DNA damage (SSB - single strand breaks). The per cent of DNA in the tail was converted to the number of SSB/109 daltons using the calibration of the method by X- ray irradiation (38). 50 cells were scored per experimental point in each experiment. The statistical significance of the difference between the DNA damage in cells treated with carcinogen only and the cells pretreated also by PEITC was tested using the Mann-Withney test.

\section{RESULTS}

\section{The Ames Test}

In the Ames test PEITC strongly reduced the mutagenicity of all concentrations of two indirect mutagens $\mathrm{AFB}_{1}$ and IQ, and the mutagenicity of direct mutagen MNU at the dose of $30 \mu \mathrm{g} / \mathrm{plate}$. The highest dose of $300 \mu \mathrm{g}$ PEITC/plate was fully toxic in combination with all mutagens and also in the sample with PEITC used alone. Other concentrations of PEITC ( 30,3 and $0.3 \mu \mathrm{g} /$ plate) did not reveal any mutagenic activity when used alone. The concentration of $30 \mu \mathrm{g}$ PEITC/plate seemed to be sligtly toxic because the number of revertants fell down below the controls.

The mutagenicity of $\mathrm{AFB}_{1}$ (concentrations of 10,1 a $0.1 \mu \mathrm{g} /$ plate in both strains of Salmonella typhimurium TA98 and TA100) was significantly reduced by the dose of $30 \mu \mathrm{g}$ PEITC/plate by 94,91 and $86 \%$ in the strain TA98, and by 88,89 and $82 \%$ in the strain TA100 (Table 1). The concentration of $3 \mu \mathrm{g} /$ plate significantly decreased the effect of three concentrations of $\mathrm{AFB}_{1}$ by 31, 65 a 37\% in the strain TA98 and by 30, 56 and $49 \%$ in the strain TA100. The lowest PEITC concentration $(0.3 \mu \mathrm{g} /$ plate $)$ had not influence on the highest concentration of $\mathrm{AFB}_{1}-10 \mu \mathrm{g} /$ plate in both strains, but mutagenicity of two lower concentrations of mutagen was reduced by this dose within the range from 15 to $37 \%$. $30 \mu$ g of PEITC in combination with $0.1 \mu \mathrm{g}$ of $\mathrm{AFB}_{1}$ reduced numbers of revertants to the levels below control numbers of revertants in both strains thus revealed possibly slight toxicity of this concentration for cells.

All three concentrations of PEITC in combination with mutagen IQ revealed statistically significant dose dependent antimutagenic activity in both strains TA98 and TA100, except combinations of
Table 3. Effect of PEITC on the mutagenicity of MNU in the Ames test (S. typhimurium TA100)

\begin{tabular}{|c|c|c|c|}
\hline \multirow{2}{*}{$\begin{array}{l}\text { MNU+PEITC dose } \\
\text { (mg/plate) }\end{array}$} & \multicolumn{3}{|c|}{ S. typhimurium TA100 } \\
\hline & $\begin{array}{l}\text { No. of rever- } \\
\text { tants }\end{array}$ & $\pm S D$ & $\%$ of inhibition \\
\hline $1,000+0$ & 1,324 & 270 & \\
\hline $1,000+0.3$ & 1,326 & 249 & 0 \\
\hline $1,000+3$ & 1,312 & 199 & -1 \\
\hline $1,000+30$ & $267^{* *}$ & 168 & -80 \\
\hline $1,000+300$ & 0 & & - \\
\hline $100+0$ & 1,594 & 157 & \\
\hline $100+0.3$ & 1,587 & 259 & 0 \\
\hline $100+3$ & 1,441 & 186 & -10 \\
\hline $100+30$ & $159 * *$ & 145 & -90 \\
\hline $100+300$ & 0 & & - \\
\hline $10+0$ & 300 & 43 & \\
\hline $10+0.3$ & 279 & 53 & -7 \\
\hline $10+3$ & 237 & 52 & -21 \\
\hline $10+30$ & $65^{* *}$ & 12 & -78 \\
\hline $10+300$ & 0 & & - \\
\hline Control (DMSO) & 83 & 11 & \\
\hline $0+0.3$ & 86 & 5 & \\
\hline $0+3$ & 94 & 3 & \\
\hline $0+30$ & 60 & 16 & \\
\hline $0+300$ & 0 & & \\
\hline
\end{tabular}

** Statistically significant difference between the sample with PEITC and mutagen and the sample with mutagen alone: $p<0.01$ SD: standard deviation

$10 \mu \mathrm{g}$ IQ/plate and $0.3 \mu \mathrm{g}$ PEITC/plate in the strain TA100 (Table 2). The dose of $30 \mu \mathrm{g}$ PEITC/plate decreased the mutagenicity of different concentrations of IQ (0.1, 0.01 a $0.001 \mu \mathrm{g} / \mathrm{plate})$ by 99, 93 and $74 \%$ in the strain TA98, the mutagenicity of $10,1 \mathrm{a}$ $0.1 \mu \mathrm{g}$ of IQ/plate by 94,87 and $60 \%$ in the strain TA 100 . The reduction of mutagenity came near to control levels of revertants and in the case of $0.1 \mu \mathrm{g}$ of IQ in the strain TA98 even below this levels. The dose of $3 \mu \mathrm{g} /$ plate reduced the effect of the same concentrations of IQ by 78, 76 a $67 \%$ in the strain TA98 and by 59,65 a $47 \%$ in TA100. The lowest concentration of $0.3 \mu$ g/plate decreased the mutagenicity by 29, 29 and $40 \%$ in the strain TA98 and by 11,33 and $25 \%$ in TA100.

$30 \mu \mathrm{g} /$ plate of PEITC strongly inhibited the mutagenicity of the direct mutagen MNU, used at the concentrations of 1000 , 100 a $10 \mu \mathrm{g} /$ plate without metabolic activation, by 80,90 a $78 \%$ in the strain TA100 (Table 3). But lower doses of PEITC were not effective. Only in a combination with two lower mutagen concentrations these doses inhibited slightly and nonsignificantly the mutagenicity of MNU. The lowest concentration of PEITC $(0.3 \mu \mathrm{g} /$ plate) was not antimutagenic in combinations with 1,000 a $100 \mu \mathrm{g} /$ plate of MNU at all. 


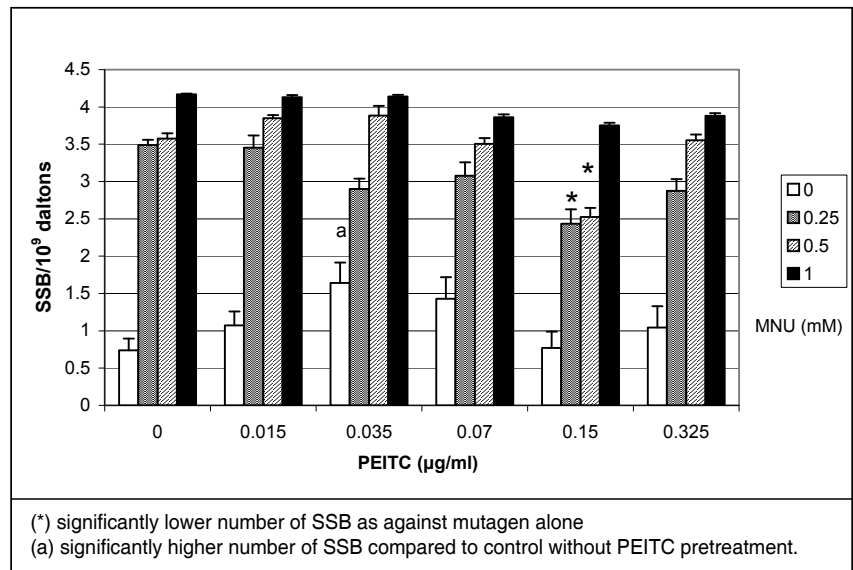

Fig. 1. Effect of PEITC on the induction of single strand DNA breaks in HepG2 cells pretreated with PEITC for $24 \mathrm{~h}$ and then treated with MNU for $1 \mathrm{~h}$.

\section{The Micronucleus Test}

In the micronucleus test all three mutagens revealed significant mutagenic activities. The numbers of micronuclei in the animals influenced by PEITC alone did not differ from those of the control group. On oral application of three doses of $25 \mathrm{mg} / \mathrm{kg}$ b.w. of PEITC before one dose of $\mathrm{AFB}_{1}(1 \mathrm{mg} / \mathrm{kg}$ b.w.), the number of micronuclei in polychromatophilic erythrocytes was lower in a statistically significant degree in comparison with the laboratory mice treated with $\mathrm{AFB}_{1}$ alone. The dose of $12.5 \mathrm{mg} / \mathrm{kg}$ b.w. decreased the number of micronuclei induced by $\mathrm{AFB}_{1}$ only insignificantly. A dose dependent antimutagenic effect was detected on the application of the IQ mutagen. Both concentrations of PEITC (three doses of 25 or $12.5 \mathrm{mg} / \mathrm{kg}$ b.w.) in combination with one dose of IQ (20 mg/kg b.w.) significantly reduced its mutagenic effect. Similarly, the treatment of mice with the combination of the same doses of PEITC and one dose of MNU ( $50 \mathrm{mg} / \mathrm{kg} \mathrm{b.w.)}$ led to a reduction of the number of micronuclei induced by MNU with significant reduction at the dose $25 \mathrm{mg} / \mathrm{kg}$ b.w. The results are presented in Table 4.

\section{The Comet Assay}

HepG2 cells were treated with diferent concentrations of PEITC for $24 \mathrm{~h}$ and then immediately for 1 hour with MNU or for 2 hours with IQ. As it is evident from the Fig.1, PEITC caused a dose dependent decrease of single strand DNA breaks (SSB) in cells treated with 0.25 or $0.5 \mathrm{mM}$ MNU. The decrese was clearly visible begining with the concentration $0.035 \mu \mathrm{g} / \mathrm{ml}$ of PEITC, being statistically significant at $0.15 \mu \mathrm{g} / \mathrm{ml}$. The higher concentration of PEITC did not show the inhibiting effect on the SSB induction, because those concentrations of PEITC caused significant induction of SSB itselves. A slight increase of SSBs in cultures treated with PEITC only was observed also at lower concentrations, being singnificant at $0.035 \mu \mathrm{g} / \mathrm{ml}$. In similar experiments we have not observed any effect of PEITC on the induction of SSB by IQ (data not shown).

\section{DISCUSSION}

In our work we revealed the strong dose-dependent inhibition effect of PEITC on the mutagenicity of two indirect mutagens $\mathrm{AFB}_{1}$ and IQ in the Ames test. On the contrary to authors who

Table 4. Impact of PEITC pretreatment on the clastogenic effect of AFB1, IQ and MNU in vivo (mice pretreated with PEITC at doses $25 \mathrm{mg} / \mathrm{kg}$ and $12.5 \mathrm{mg} / \mathrm{kg}$ b.w. for three consecutive days before administration of mutagens)

\begin{tabular}{|c|c|c|}
\hline Substances studied & No. of micronuclei \pm SD & K \\
\hline Control - 7\% DMSO & $0.5 \pm 0.6$ & \\
\hline PEITC - 3x12.5 mg/kg & $0.4 \pm 0.5$ & 0.8 \\
\hline PEITC - 3×25 mg/kg & $0.4 \pm 0.5$ & 0.8 \\
\hline Control - 7\% DMSO & $0.8 \pm 1.0$ & \\
\hline AFB1 - $1 \mathrm{mg} / \mathrm{kg}$ & $5.0^{\mathrm{aa}} \pm 1.4$ & 6.3 \\
\hline PEITC + AFB1 - 3x12.5 mg/kg + $1 \mathrm{mg} / \mathrm{kg}$ & $3.7^{\mathrm{aa}} \pm 1.2$ & 4.6 \\
\hline PEITC + AFB1 - 3×25 mg/kg + 1 mg/kg & $1.7^{\star \star} \pm 0.5$ & 2.1 \\
\hline Control - 7\% DMSO & $0.7 \pm 0.8$ & \\
\hline $\mathrm{IQ}-20 \mathrm{mg} / \mathrm{kg}$ & $4.3^{\mathrm{aa}} \pm 0.8$ & 6.1 \\
\hline PEITC + IQ - 3X12.5 mg/kg + 20 mg/kg & $2.7^{\star \star a a} \pm 0.8$ & 3.9 \\
\hline PEITC + IQ - 3x25 mg/kg + 20 mg/kg & $1.8^{\star \star a} \pm 0.8$ & 2.6 \\
\hline Control - 7\% DMSO & $0.5 \pm 0.5$ & \\
\hline MNU $50 \mathrm{mg} / \mathrm{kg}$ & $14.7^{\text {aa }} \pm 4.5$ & 29.4 \\
\hline PEITC + MNU - 3x12.5 mg/kg + $50 \mathrm{mg} / \mathrm{kg}$ & $12.7^{\mathrm{aa}} \pm 0.5$ & 25.4 \\
\hline PEITC + MNU -3x25 mg/kg + 50 mg/kg & $8.3^{\star a a} \pm 1.2$ & 16.6 \\
\hline
\end{tabular}

** significantly lower number of micronuclei as against mutagen alone, $p<0.01$

* significantly lower number of micronuclei as against mutagen alone, $p<0.05$

aa significantly lower number of micronuclei as against control, $\mathrm{p}<0.01$

${ }^{a}$ significantly lower number of micronuclei as against control, $p<0.05$

$\mathrm{SD}$ - standard deviation

$\mathrm{K}$ - ratio of induced to spontaneous micronucleus levels 
describe strong genotoxic effect of PEITC in vitro and slight genotoxic effect in vivo (39) we did not proved any mutagenic activity of this compound in the Ames and the micronucleus tests, but concentration of $300 \mu \mathrm{g} /$ plate was toxic in the Ames test. The antimutagenic effect against the direct mutagen MNU was detected only at concentration of $30 \mu \mathrm{g} /$ plate in the Ames test. In some experiments the concentration of $30 \mu \mathrm{g} /$ plate of PEITC revealed antiproliferative or slight bacteriotoxic effects, because the number of revertants was reduced below the control levels. Also in vivo PEITC reduced a number of micronuclei in mice exposed to all three mutagens. Similar antimutagenic activity of PEITC on mutagenicity of heterocyclic amines in the Ames test was achieved by Hamilton and Teel (29). Knasmüller et al. (28) measured the mutagenic activity of dimethylnitrosamine and 2amino-1-methyl-6-phenylimidazo[4,5-b] pyridine after metabolic activation with S9 homogenate from organs of PEITC treated mice and also proved a reduction of mutagenicity.

Antimutagenic and anticarcinogenic effects of PEITC are caused by the influence on a metabolic activation of mutagen by the inhibition of the level and/or activity of CYP enzymes and also by the effect on detoxification enzymes $(15,29,40)$. PEITC has also the antiproliferative effect and induces apoptosis (24, $41,42)$. Described bacteriotoxic effect of ITCs $(24,43)$ suggests that the stimulation of apoptosis by chemopreventive agents may often reflect occurrence of toxic effects at high doses.

In our experiments strong bacteriotoxic effect was proved at a concentration of $300 \mu \mathrm{g}$ PEITC/plate in the Ames test. Antiproliferative or slightly cytotoxic effect of a concentration of $30 \mu \mathrm{g} /$ plate of PEITC was probably the main reason for the antimutagenicity against the direct mutagen MNU. The strong antimutagenic effect against the indirect mutagens $\mathrm{AFB}_{1}$ and IQ is possibly result of influences on metabolic activation and detoxification of mutagens combined with antiproliferative effects at higher concentrations of PEITC, at lower concentrations of PEITC the effect on mutagen metabolism is predominant.

In contrast to findings of Arranz et al. (31), who described the PEITC-caused reduction of SSB induced by N-nitrosamine in HepG2 cells, we have not seen any PEITC- caused reduction of SSB induced by IQ. Our results are in accordance with findings of García et al. (44), who found a weak protective effect of PEITC towards $\mathrm{N}$-nitrosodibutylamine or $\mathrm{N}$-nitrosopiperidine oxidative DNA damage in the single cell gel electrophoresis (SCGE)/HepG2 assay. On the other hand, rather surprising was our finding that PEITC is able to reduce the induction of DNA damage by directly acting alkylating agent MNU. This, to our knowledge, has not been described, and it seems to support the view, that PEITC is able to induce the phase II detoxification enzymes $(45,46)$.

PEITC and other isothiocyanates appear to have many favourable properties including antimutagenic effect and that make them attractive for other study and development as chemopreventive agents for human cancer and some other human pathologies that share some common pathogenetic mechanisms.

\section{Acknowledgements.}

The authors wish to thank Mrs. M. Benešová, Mrs.V. Filipiová, and Mrs. J. Jalovecká for their skilfull technical assistance.

Supported by the Ministry of Health of the Czech Republic, Project No. NR 8985

\section{REFERENCES}

1. Surh YJ. Cancer chemoprevention with dietary phytochemicals. Nat Rev Canc. 2003 Oct;3(10):768-80.

2. Aggarwal BB, Shishodia S. Molecular targets of dietary agents for prevention and therapy of cancer. Biochem Pharmacol. 2006 May 14;71(10):1397-421.

3. De Flora S, Ferguson LR. Overview of mechanisms of cancer chemopreventive agents. Mutat Res. 2005 Dec 11;591(1-2):8-15.

4. Kelloff GJ, Crowell JA, Steele VE, Lubet RA, Malone WA, Boone ChW, et al. Progress in cancer chemoprevention: development of diet-derived chemopreventive agents. J Nutr. 2000 Feb;130(2S Suppl):467S-71S.

5. Dorai T, Aggarwal BB. Role of chemopreventive agents in cancer therapy. Cancer Lett. 2004 Nov 25;215(2):129-40.

6. Šmerák P, Šestáková H, Polívková Z, Bárta I, Turek B, Bártová J, et al. Antimutagenic effect of ellagic acid and its effect on the immune response in mice. Czech J Food Sci. 2002;20(5):181-91.

7. Šmerák P, Polívková Z, Šestáková H, Štětina R, Bárta I, Langová M, et al. Antimutagenic effect of curcumin and its effect on the immune response in mice. Czech J Food Sci. 2006;24(2):72-83.

8. Šmerák P, Šestáková H, Polívková Z, Štětina R, Langová M, Bárta I, et al. Antimutagenic effect of epigallocatechin gallate and its effect on the immune response in mice. Czech J Food Sci. 2006;24(4):180-92.

9. Bárta I, Šmerák P, Polívková Z, Šestáková H, Langová M, Turek B, et al. Current trends and perspectives in nutrition and cancer prevention. Neoplasma. 2006;53(1):19-25.

10. Polívková Z, Langová M, Šmerák P, Bártová J, Bárta I. Antimutagenic effect of genistein. Czech J Food Sci. 2006;24(3):119-26.

11. Steinmetz KA, Potter JD. Vegetables, fruit, and cancer prevention: a review. J Am Diet Assoc. 1996 Oct;96(10):1027-39.

12. Hecht SS. Inhibition of carcinogenesis by isothiocyanates. Drug Metab Rev. 2000 Aug-Nov;32(3-4):395-411.

13. Hecht SS. Chemoprevention of cancer by isothiocyanates, modifiers of carcinogen metabolism. J Nutr. 1999 Mar;129(3):768S-774S.

14. Zhang Y. Cancer-preventive isothiocyanates: measurement of human exposure and mechanism of action. Mutat Res. 2004 Nov 2;555(1-2):173-90.

15. Vang O. Chemopreventive potential of compounds in cruciferous vegetables. In: Baer-Dubowska W, Bartoszek AB, Gianti DM, editors. Carcinogenic and anticarcinogenic food components. Boca Raton: CRC Taylor\&Francis group; 2006. p. 303-28.

16. Von Weymarn LB, Chun JA, Hollenberg PF. Effects of benzyl and phenethyl isothiocyanate on P450s 2A6 and 2A13: potential for chemoprevention in smokers. Carcinogenesis. 2006 Apr;27(4):782-90.

17. Chung FL. Chemoprevention of lung cancer by isothiocyanates and their conjugates in A/J mouse. Exp Lung Res. 2001 Apr-May;27(3):319-30.

18. Conaway CC, Wang CX, Pittman B, Yang YM, Schwartz JE, Tian D, et al Phenethyl isothiocyanate and sulforaphane and their N-acetylcysteine conjugates inhibit malignant progression of lung adenomas induced by tobacco carcinogens in A/J mice. Cancer Res. 2005 Sep 15;65(18):8548-57.

19. Solt DB, Chang K, Helenowski I, Rademaker AW. Phenethyl isothiocyanate inhibits nitrosamine carcinogenesis in a model study of oral cancer. Cancer Lett. 2003 Dec 30;202(2):147-52.

20. Nishikawa A, Furukawa F, Lee IS, Tanaka T, Hirose M. Potent chemopreventive agents against pancreatic cancer. Curr Cancer Drug Targets. 2004 Jun;4(4):373-84.

21. Xiao D, Lew KL, Zeng Y, Xiao H, Marynowski SW, Dhir R, et al. Phenethyl isothiocyanate-induced apoptosis in PC-3 human prostate cancer cells is mediated by reactive oxygen species-dependent disruption of the mitochondrial membrane potential. Carcinogenesis. 2006 Nov;27(11):2223-34.

22. Zhang Y, Tang L, Gonzalez V. Selected isothiocyanates rapidly induce growth inhibition of cancer cells. Mol Cancer Ther. 2003 Oct;2(10):1045-52.

23. Tseng E, Scott-Ramsay EA, Morris ME. Dietary organic isothiocyanates are cytotoxic in human breast cancer MCF-7 and mammary epithelial MCF-12A cell lines. Exp Biol Med. 2004 Sep;229(8):835-42.

24. D’Agostini F, Izzotti A, Balanski RM, Bennicelli C, De Flora S. Modulation of apoptosis by cancer chemopreventive agents. Mutat Res. 2005 Dec 11;591(1-2):173-86.

25. Xiao D, Singh SV. Phenethyl isothiocyanate inhibits angiogenesis in vitro and ex vivo. Cancer Res. 2007 Mar 1;67(5):2239-46.

26. Wang LG, Beklemisheva A, Liu XM, Ferrari AC, Feng J, Chiao JW. Dual action on promoter demethylation and chromatin by an isothiocyanate restored GSTP1 silenced in prostate cancer. Mol Carcinog. 2007 Jan;46(1):24-31.

27. Pullar JM, Thomson SJ, King MJ, Turnbull CI, Midwinter RG, Hampton 
MB. The chemopreventive agents phenethyl isothiocyanate sensitizes cells to Fas-mediated apoptosis. Carcinogenesis. 2004 May;25(5):765-72.

28. Knasmüller S, Friesen MD, Holme JA, Alexander J, Sanyal R, Kassie F,et al. Effects of phenethyl isothiocyanate on metabolism and on genotoxicity of dimethylnitrosamine and 2-amino-1-methyl-6-phenylimidazo[4,5-b] pyridine (PhIP). Mutat Res. 1996 Feb 19;350(1):93-102.

29. Hamilton SM, Teel RW. Effects of isothiocyanates on cytochrome P450 1A1 and 1A2 activity and on the mutagenicity of heterocyclic amines. Anticancer Res. 1996 Nov-Dec;16(6B):3597-602.

30. Sen S, Mukherjee A, Agarwal K, Sharma A. Phenethyl isothiocyanate modulates clastogenicity of mitomycin $\mathrm{C}$ and cyclophosphamide in vivo. Mutat Res. 1996 Dec 20;37(3-4):159-64.

31. Arranz N, Haza AI, Garcia A, Möller L, Rafter J, Morales P. Protective effects of isothiocyanates towards $\mathrm{N}$-nitrosamine-induced DNA damage in the single-cell gel electrophoresis (SCGE)/HepG2 assay. J Appl Toxicol. 2006 Nov-Dec;26(6):493-9.

32. Ames BN, McCann J, Yamasaki E. Methods for detection of carcinogens and mutagens with Salmonella/mammalian-microsome mutagenicity test. Mutat Res. 1975 Dec;31(6):347-64.

33. Maron DM, Ames BN. Revised methods for the Salmonella mutagenicity test. Mutat Res. 1983 May;113(3-4):173-215.

34. Černá M, Dobiáš L, Hájek V. The Ames method. V: Methods for the biological monitoring ot the genotoxic effects of environmental factors - standard methodology. Acta Hyg Epidemiol Microbiol. 1989;Suppl 20:33-56. (In Czech.)

35. Schmid W. The micronucleus test. Mutat Res. 1975 Feb;31(1):9-15.

36. Singh NP, McCoy MT, Tice RR, Schneider EL. A simple technique for quantitation of low levels of DNA damage in individual cells. Exp Cell Res. 1988 Mar;175(1):184-91.

37. Collins AR, Dobson VL, Dusinská M, Kennedy G, Štětina R. The comet assay: what can it really tell us? Mutat Res. 1997 Apr 29;375(2):183-93.

38. Collins AR, Dušinská M, Gedik C, Štětina R. Oxidative damage to DNA: do we have a reliable biomarker? Environ Health Perspect. 1996 May;104 Suppl 3:465-9.

39. Kassie F, Knasmüller S. Genotoxic effects of allyl isothiocyanate (AITC) and phenethyl isothiocyanate (PEITC). Chem Biol Interact. $2000 \mathrm{Jul}$ 3;127(2):163-80.

40. Zhang Y, Talalay P. Anticarcinogenic activities of organic isothiocyanates: chemistry and mechanisms. Cancer Res. 1994 Apr 1;54(7 Suppl):1976S1981S.

41. Huang C, Ma WY, Li J, Hecht SS, Dong Z. Essential role of p53 in phenethyl isothiocyanate-induced apoptosis. Cancer Res. 1998 Sep 15;58(18):4102-6.

42. Chiao JW, Wu H, Ramaswamy G, Conaway CC, Chung FL, Wang L, et al. Ingestion of an isothiocyanate metabolite from cruciferous vegetables inhibits growth of human prostate cancer cell. Carcinogenesis. 2004 Aug;25(8):1403-8.

43. Lin CM, Preston JF, Wei CI. Antibacterial mechanism of allyl isothiocyanate. J Food Prot. 2000 Jun;63(6):727-34.

44. García A, Haza AI, Arranz N, Rafter J, Morales P. Protective effects of isothiocyanates alone or in combination with vitamin $C$ towards $\mathrm{N}$ - nitrosodibutylamine or N-nitrosopiperidine-induced oxidative DNA damage in the single-cell gel electrophoresis (SCGE)/HepG2 assay. J Appl Toxicol. 2008 Mar;28(2):196-204.

45. Thornalley PJ. Isothiocyanates: mechanism of cancer chemopreventive action. Anticancer Drugs. 2002 Apr;13(4):331-8.

46. Zhang Y. Cancer-preventive isothiocyanates: measurement of human exposure and mechanism of action. Mutat Res. 2004 Nov 2;555(1-2):173190.

Received October 27, 2008 Accepted in revised form December 12, 2008 